AJST

amca2012.org

\title{
The impact of Covid-19 on chicken broiler farm business in Malang Regency
}

\author{
Sutraning Nurahmi ${ }^{1}$ and Lili Zalizar ${ }^{1, *}$ \\ ${ }^{1}$ University of Muhammadiyah Malang, Indonesia \\ ${ }^{*}$ Corresponding author: lilizalizar62@gmail.com
}

\author{
KEYWORDS \\ Broiler \\ COVID-19 impact \\ Livestock business \\ Supply-demand
}

SUBMITTED 15 Dec 2020

REVISED 5 Jan 2021

ACCEPTED 25 Jan 2021

\begin{abstract}
The contagious COVID-19 spreads rapidly worldwide. The pandemic poses risks to multiple sectors of the world economy, including the agricultural and livestock sectors. Despite the economic potential of broiler farm business, indicated by its increasing broiler population, production, and public consumption, the large-scale social restrictions imposed by the government as an effort to mitigate the pandemic spread has decreased the demand for and supply of broiler meat. This current study is aimed at obtaining an overview on the impact that the COVID-19 pandemic has on the broiler farm business in Malang Regency. The data of this qualitative descriptive study were collected by means of interviews, personal documentation, and other supporting documents. Sampling was carried out using stratified random sampling technique as the broiler population was non-homogenous and stratified. The broiler population was divided into two groups: 1) less than 5,000 heads broiler-population; and 2) more than 5,000 heads broiler-population. The study results showed that the negative impact caused by the pandemic on the broiler farm business include declines in the broiler meat selling prices, farmers' income, and broiler population. The decline in selling prices is caused by the broiler supplydemand imbalance and changes in the public consumption patterns during pandemic, favouring food ingredients with longer durability. The farmers' income decline occurs as a result of the dropping price of live broilers combined with the extra costs that the farmers have to spend to keep the business operating during the pandemic. Finally, the decline in broiler population takes place because of chick-in cancellation to suppress excess supply at the following harvest period. The broiler population restriction controls are conducted in order to regulate prices at the consumer level.
\end{abstract}

(c) The Author(s) 2021.

\section{INTRODUCTION}

The infectious coronavirus disease (COVID-19) has profoundly affected peace across the globe due to its rapid spread. On January 30, 2020, the WHO declared the COVID-19 outbreak an epidemic and elevated the status as a global pandemic on March 11, 2020. The pandemic is spreading extensively worldwide and has created formidable disruptions to various sectors of the world economy, including agricultural and livestock sectors. Indonesia has seen a decline in the two sectors due to the government's large-scale social restriction measures (PSBB) affecting the agricultural and livestock product distribution. This eventually drops both sectors' demand and product prices during the harvest time [1]-[3]. Broiler meat is considered as an easily available source of animal protein with relatively affordable price. Broiler farming also plays an important role in enriching the life of the nation by helping the people meet the essential nutrients. Hence, the business has a great potential to be further developed. This potential could be measured from the nation's constantly growing population, productivity, and consumption. However, the increase in productivity and consumption are to be in line with the growths in population, income, and public awareness of nutritional needs of the people. The culti- vation of broilers has been considered as relatively easy because the fast-growing birds are characterised as to have high meat productivity, efficiency of feed utilisation, and quick harvesting age [4], [5].

Despite the potential of broiler farm business, the imposition of large-scale social restrictions has caused losses in various economic sectors, including the livestock agriculture sector. Furthermore, prolonged restrictions potentially risk the survival capacity of the economy sectors, leading to greater losses both economically and socially. The impact that occurs should not be underestimated as it is directly linked to the basic human needs. The impact leads to changes in market prices, slow and reduced supply chains, deteriorating health of livestock farmers, labour reduction, and other disruptions. The losses suffered by Indonesia due to the pandemic were also affected by the economic growth of China, one of Indonesia's major trading partners for import and export, especially for non-oil and gas commodity [6]-[8].

The global spread of COVID-19 pandemic has not only disrupted the business of livestock agriculture, but also caused food crises in Indonesian regions. Livestock oversupply, distribution difficulties, feed rising costs, increasing farmers' debt, and the absence of government's inter- 
vention in regulating the chicken's market price have been some of the problems faced by Indonesian broiler farmers caused by the pandemic. Meanwhile, long-term losses in the broiler farm business may include a decline in business productivity, a reduction in the number of labourers, and termination of business activities. An imbalance between product supply and demand will occur as a result of supply chains disruption. When the product supply is high and the demand is low, the price of broiler meat will inevitably decline. This price decline due to oversupply will potentially lead to the chick-in cancellation in some broiler breeder farms[4], [9].

Based on the aforementioned situations, this current study aims at obtaining an overview of the COVIC-19 impact on the broiler farm business in Malang Regency, East Java, Indonesia. The results of this study are to minimise the indirect impact of the COVID-19 pandemic on the broiler livestock sector. The object of the study were broiler farmers of Malang Regency.

\subsection{Broiler Farm}

Broilers are categorised into cross-bred meat producer poultry with a fast-growing ability and high productivity. Broiler meat is relatively affordable and requires easy preparation, making it a favourite protein source of many households. The broiler population, production, and consumption have continued to increase in the last decade. Additionally, poultry business has been a sector responsible for supplying $65 \%$ of the protein needs and providing $10 \%$ employment of the national workforce. Around $60 \%$ of the production comes from poultry farming using a closed housing system, and the rest $40 \%$ originates from ones with an open housing system [4], [5].

The superiority of broilers is supported by the genetic characteristics of the birds and the conditions of the poultry housing environment. Optimising broiler performance can be achieved with a modern intensive housing system. The broiler performance can be measured through its mortality, feed consumption, final weight, feed conversion ratio, and performance index. The housing system used can greatly influence the success of broiler farming. Therefore, it must be carefully maintained, especially its temperature, humidity, and air circulation. The closed housing system is an effort to achieve a comfortable environment, healthy air, and minimised stress conditions. This housing system is able to reduce the impact of high humidity as its walls are closed and made of permanent materials accompanied by the use of high technology [10], [11].

\section{METHODS}

This qualitative descriptive study aims at investigating the impact of COVID-19 pandemic on the broiler farm business in Malang Regency. The study was conducted in October 2020 in Malang Regency. A purposive sampling was employed to decide the study location as Malang Regency is one of the centres of broiler production. Sampling was carried out using stratified random sampling technique because the livestock population was non-homogenous and stratified. The broiler population was divided into two groups: 1) less than 5,000heads broiler-population; and 2) more than 5,000heads broiler-population. Data collection techniques are carried out by means of interviews, personal documentation, and other supporting documents. The as- pects being studied were the broiler selling price, farmer's income, and DOC (Day Old Chicken) price.

\section{RESULTS AND DISCUSSION}

The study results were based on 10 respondents representing broiler farmers in Wonosari District and Kromengan District of Malang Regency. The results revealed that COVID-19 pandemic has negatively impacted the broiler livestock sector in the regency. The large-scale social restriction (PSBB) policy, as an effort to mitigate the spread of the pandemic, has impacted the distribution of livestock products as well as decreased the public purchasing power. The pandemic has situated the broiler farmers in difficulty due to significant drop in the broiler selling prices. This leads to a decline in farmers' income and a reduction in the livestock population in order to suppress and control the excess supply at the next harvest period. This eventually affects the survival of broiler farmers in the long term. The following are the results of the study on the impact of COVID-19 pandemic on the broiler farm business:

\subsection{Decline in Broiler Selling Price}

The spread of COVID-19 pandemic has caused the selling price of broiler meat to gradually decline due to the largescale social restriction (PSBB) policy imposed by the government. Any forms of public activity and access to transportation are restricted, which in turn decreases public purchasing power and consumption on broiler meat. This social restriction policy affects the inter-city distribution of broiler product, resulting in supply chain disruption. As there is an imbalance between supply and demand, the price of broiler meat drops. The price decline is particularly due to the broiler meat excess supply. At the beginning of COVID-19 pandemic spread in Indonesia, broiler farmers sold a live DOC broiler for IDR 9,000 per kilogram; it's far below the actual production cost of IDR 17,000 per kilogram. However, the government's social restriction policy was not the only factor causing the broiler meat price to drop. The decline was also influenced by the public changing consumption patterns during the pandemic. Public prefers to consume processed or pre-packaged food that has better durability and avoids grocery shopping at wet markets. This price decline in live chicken sales affects the income of broiler farmers during the harvest season.

\subsection{Decline in Farmers' Income}

The broiler farmers have seen a decline in their income during the early spread of COVID-19 pandemic in Indonesia. This price drop occurs due to a decrease in the selling price of live DOC broilers as well as due to the excess supply of chicken meat. Additional factor contributing to the farmers' decreased income is that the farmers are required to spend extra for farming maintenance, supervision, and other production costs. Acerbating these conditions, the spread of COVID-19 pandemic caused broiler farmers to lose their market due to social activity restrictions, changes in public consumption patterns, and decreased public demand.

\subsection{Decline in Broiler Population}

Excess supply of broiler meat has resulted in the restriction to the cancellation of chick-in in some broiler breeder 
farms (parent stock). This restriction was carried out to reduce the excess supply of broiler chickens at the upcoming harvest period. The decline in demand for DOC by poultry businesses is due to the unstable market prices of the broiler meat at the consumer level. As the broiler population declines, the farmers' income will also decline. Largescale farmers will reduce the broiler population during the COVID-19 pandemic in order to mitigate possible losses as well as to control prices. Meanwhile, small-scale broiler farmers are likely to terminate their business as they have less business survival resilience during the pandemic.

\section{CONCLUSION}

Based on the results of the study, the COVID-19 pandemic has negative impacts on the survival of broiler farm businesses. The downsides include declines in the broiler meat price, farmers' income, and broiler population. The decline in price is caused by the supply-demand imbalance due to oversupply in the broiler breeder farms as well as changes in the public consumption patterns during pandemic, which features less broiler meat intake. The second impact, farmers' decreased income, occurs as a result of broiler dropping selling prices combined with the extra costs that the farmers have to spend to keep the business operating during the pandemic. Finally, the decline in broiler population takes place because of chick-in cancellation in a number of broiler breeder farms as an effort to reduce the harvest time oversupply so that the chicken meat price circulating in the markets could be controlled.

\section{REFERENCES}

[1] D. A. D. Nasution, Erlina, and I. Muda, "Dampak Pandemi COVID-19 Terhadap Perekonomian Indonesia," J. Benefita, vol. 5, no. 2, pp. 212-224, 2020.

[2] N. K. Muliati, "Pengaruh Perekonomian Indonesia di Berbagai Sektor Akibat Corona Virus Disease 2019 (Covid-19)," Widya Akunt. dan Keuang., pp. 78-86, 2020.

[3] S. Hanoatubun, "Dampak Covid-19 Terhadap Perekonomian Indonesia," J. Educ. Psychol. Couns., vol. 2, no. 1, pp. 146-153, 2020.

[4] V. Armelia, N. D. Arkan, Isomoyowati, and N. A. Setianto, "Dampak Sosial Ekonomi COVID-19 Terhadap Usaha Peternakan Broiler di Indonesia," in Prospek Peternakan di Ea Normal Baru Pasca PAndemi COVID-19, 2020, pp. 161-167.

[5] Pusat Data dan Sistem Informasi Pertanian, Buku Outlook Komoditas Peternakan Daging Ayam Ras Pedaging. 2019.

[6] MedfoTeam, "Covid-19: Dampak Terhadap Sektor Pertanian dan Peternakan," CATTLE BUFFALO CLUB, 2020. [Online]. Available: http://cattlebuffaloclub. peternakan.unpad.ac.id/2020/05/10/covid19-dampak-terhadap-sektor-pertanian-danpeternakan/.

[7] W. Hadiwardoyo, "Kerugian Ekonomi Nasional Akibat Pandemi Covid-19," Baskara J. Bus. Enterpreneursh., vol. 2, no. 2, pp. 83-92, 2020.

[8] E. Budiyanti, "Dampak Virus Corona Terhadap Sektor Perdagangan Dan Pariwisata Indonesia," Kaji. Bid. Ekon. Dan Kebijak. Publik, vol. XII, no. 4, pp. 19-24, 2020.

[9] Anonim, "Laporan Kondisi Peternakan Ayam Akibat Wabah Virus Corona," 2020.
[10] M. K. Umam, H. S. Prayogi, and V. M. A. Nurgiartiningsih, "Penampilan Produksi Ayam Pedaging yang Dipelihara pada Sistem Lantai Kandang Panggung dan Kandang Bertingkat," J. Ilmu-Ilmu Peternak., vol. 24, no. 3, pp. 79-87, 2015.

[11] T. Nuryati, "Analisis Performans Ayam Broiler Pada Kandang Tertutup dan Kandang Terbuka," J. Peternak. Nusant., vol. 5, no. 2, pp. 77-86, 2019. 